\title{
Characterization of circulating T-, NK-, and NKT cell subsets in patients with colorectal cancer: the peripheral blood immune cell profile
}

\author{
Daniëlle Krijgsman ${ }^{1,2}$ - Natasja L. de Vries ${ }^{1,2} \cdot$ Anni Skovbo $^{2,3} \cdot$ Morten N. Andersen $^{2} \cdot$ Marloes Swets $^{1} \cdot$ \\ Esther Bastiaannet ${ }^{1}$. Alexander L. Vahrmeijer ${ }^{1}$. Cornelis J. H. van de Velde ${ }^{1}$ - Mirjam H. M. Heemskerk ${ }^{4}$. \\ Marianne Hokland ${ }^{2} \cdot$ Peter J. K. Kuppen ${ }^{1}$
}

Received: 28 September 2018 / Accepted: 16 April 2019 / Published online: 3 May 2019

(c) The Author(s) 2019

\begin{abstract}
Objective As the development and progression of colorectal cancer (CRC) are known to be affected by the immune system, cell subsets such as T cells, natural killer (NK) cells, and natural killer T (NKT) cells are considered interesting targets for immunotherapy and clinical biomarker research. Until now, the role of systemic immune profiles in tumor progression remains unclear. In this study, we aimed to characterize the immunophenotype of circulating T cells, NK cells, and NKT-like cells in patients with CRC, and to subsequently correlate these immunophenotypes to clinical follow-up data.

Methods Using multiparameter flow cytometry, the subset distribution and immunophenotype of $\mathrm{T}$ cells $\left(\mathrm{CD}^{+} \mathrm{CD}^{+} 6^{-}\right)$, $\mathrm{CD}^{\text {dim }}{ }^{\mathrm{NK}}$ cells $\left(\mathrm{CD}^{-}{ }^{-} \mathrm{CD} 56^{\mathrm{dim}}\right)$, CD56 ${ }^{\text {bright }} \mathrm{NK}$ cells $\left(\mathrm{CD} 3^{-} \mathrm{CD} 56^{\text {bright }}\right)$, and NKT-like $\left(\mathrm{CD} 3^{+} \mathrm{CD} 56^{+}\right)$cells were investigated in peripheral blood mononuclear cell (PBMC) samples from 71 CRC patients and 19 healthy donors.

Results CRC patients showed profound differences in immune cell subset distribution and their immunophenotype compared to healthy donors, as characterized by increased percentage of regulatory $\mathrm{T}$ cells, and reduced expression level of the natural cytotoxicity receptors NKp44 and NKp46 on both CD56 ${ }^{\mathrm{dim}}$ NK cells and NKT-like cells. Finally, we showed in a multivariate analysis that above-median percentage of $\mathrm{CD} 16^{+}$NKT-like cells was independently associated with shorter disease-free survival in CRC patients.

Conclusion The altered phenotype of circulating immune cell subsets in CRC and its association with clinical outcome highlight the potential use of PBMC subsets as prognostic biomarkers in CRC, thereby contributing to better insight into the role of systemic immune profiles in tumor progression.
\end{abstract}

Keywords Colorectal cancer - Peripheral blood immune cell profile $\cdot$ Cancer immunology $\cdot$ Natural cytotoxicity receptors . Tumor progression $\cdot$ Prognostic biomarkers

Daniëlle Krijgsman and Natasja L. de Vries equally contributed to this study.

Marianne Hokland and Peter J.K. Kuppen are equally responsible for this study.

Electronic supplementary material The online version of this article (https://doi.org/10.1007/s00262-019-02343-7) contains supplementary material, which is available to authorized users.

Peter J. K. Kuppen

p.j.k.kuppen@lumc.nl

1 Department of Surgery, Leiden University Medical Center, Albinusdreef 2, 2300 RC Leiden, The Netherlands

2 Department of Biomedicine, Aarhus University, Aarhus, Denmark

$\begin{array}{ll}\text { Abbreviations } \\ \text { ADCC } & \begin{array}{l}\text { Antibody-dependent cell-mediated } \\ \text { cytotoxicity }\end{array} \\ \text { CI } & \text { Confidence interval } \\ \text { CRC } & \text { Colorectal cancer } \\ \text { CS\&T } & \text { Cytometer setup and tracking } \\ \text { DFS } & \text { Disease-free survival } \\ \text { DNAM-1 } & \text { DNAX accessory molecule-1 } \\ \text { FM2 } & \text { Fluorescence minus two }\end{array}$

3 FACS Core Facility, Aarhus University, Aarhus, Denmark

4 Department of Hematology, Leiden University Medical Center, Leiden, The Netherlands 


$\begin{array}{ll}\text { FMO } & \text { Fluorescence minus one } \\ \text { HR } & \text { Hazard ratio } \\ \text { HIF-1 } \alpha & \text { Hypoxia-inducible factor (HIF)-1 } \alpha \\ \text { Ig } & \text { Immunoglobulin } \\ \text { LUMC } & \text { Leiden University Medical Center } \\ \text { MFI } & \text { Median fluorescence intensity } \\ \text { NCR } & \text { Natural cytotoxicity receptor } \\ \text { NK } & \text { Natural killer } \\ \text { NKG2A } & \text { Natural killer group 2-A } \\ \text { NKG2C } & \text { Natural killer group 2-C } \\ \text { NKG2D } & \text { Natural killer group 2-D } \\ \text { NKT } & \text { Natural killer T } \\ \text { PBMC } & \text { Peripheral blood mononuclear cell } \\ \text { PCNA } & \text { Proliferating cell nuclear antigen } \\ \text { Treg } & \text { Regulatory T cells } \\ \text { SD } & \text { Standard deviation } \\ \text { TME } & \text { Tumor microenvironment } \\ \text { TNM } & \text { Tumor-node metastasis }\end{array}$

\section{Introduction}

Colorectal cancer (CRC) is a major contributor to cancerrelated morbidity and mortality [1]. Approximately one million new cases of CRC arise per year throughout the world, with more than half a million deaths annually [1]. For colorectal tumors that have not spread to distant sites, surgery is the primary treatment [2]. However, around 25\% of the patients present with unresectable metastatic disease at the time of diagnosis, and up to $50 \%$ percent of earlystage patients develop recurrence or dissemination of the disease following surgery [3]. To reduce the risk of relapse and to prolong the survival of patients with metastatic disease, treatment strategies need to be optimized. Therefore, biomarker application is important since it provides information for therapeutic decision making. As the development and progression of CRC are known to be affected by the immune system, cell subsets such as T cells, natural killer (NK) cells, and natural killer T (NKT) cells are considered interesting targets for immunotherapy and clinical biomarker research. Importantly, the phenotype of circulating lymphocyte subsets may reflect the local immune response in the tumor microenvironment (TME), thereby providing potentially important information regarding disease progression in CRC [4-6].

Different T-cell subsets have been described over the years, each with distinct functions that promote, or inhibit, antitumor immune responses. For instance, cytotoxic $\left(\mathrm{CD}^{+}\right) \mathrm{T}$ cells recognize tumor-associated antigens presented by classical HLA class I molecules. Additionally, $\mathrm{CD} 4^{+} \mathrm{T}$ cells play an important regulatory role via secretion of cytokines and activation of cytotoxic $\mathrm{T}$ cells and $B$ cells [7]. Regulatory $T$ cells $\left(\mathrm{T}_{\text {reg }}\right)$, a subpopulation of
$\mathrm{CD} 4^{+} \mathrm{T}$ cells, have an immunosuppressive function [8]. To escape immune recognition by cytotoxic $\mathrm{T}$ cells, tumor cells may downregulate classical HLA class I expression [9]. Studies showed that aberrant HLA class I expression commonly occurs in colorectal tumors [10-14]. These tumors represent potential targets for NK cells [15], which are known to be able to recognize and kill tumor cells with downregulated HLA class I molecules [16, 17].

NK cells can be subdivided based on their CD56 expression: CD56 $6^{\text {bright }} \mathrm{NK}$ cells are generally associated with immunoregulatory properties and production of proinflammatory cytokines, while CD56 ${ }^{\mathrm{dim}} \mathrm{NK}$ cells primarily exert cytotoxic functions $[18,19]$. The NK cell activity is dependent on a delicate balance between activating and inhibitory signals from cell surface receptors [20]. The activating signals are mediated by a wide array of receptors including natural killer group 2-C (NKG2C), natural killer group 2-D (NKG2D), DNAX accessory molecule-1 (DNAM-1), CD161, and natural cytotoxicity receptors (NCRs) NKp30, NKp44, and NKp46. Additionally, CD16 (FcrRIII) on NK cells mediates antibody-dependent cellmediated cytotoxicity (ADCC) [21]. Furthermore, CD8 is considered a stimulatory cell surface receptor since it enhances the cytolytic activity of NK cells [22]. NK cells also express a range of receptors that provide inhibitory signals upon stimulation. NK cell inhibitory receptors include natural killer group 2-A (NKG2A), and killer cell immunoglobulin (Ig)-like receptors CD158a and CD158b.

Apart from NK- and T cells, peripheral blood comprises other leucocyte subsets with the ability to induce antitumor effects. For instance, NKT cells constitute a unique subset of $T$ cells that lie at the interface between innate and adaptive immunity. Unlike conventional T cells, NKT cells express a $\mathrm{T}$ cell receptor that recognizes glycolipids presented by the HLA-like molecule CD1d [23]. Besides, NKT cells express various markers typically associated with NK cells (activating and inhibitory cell-surface receptors) [24]. NKT cells possess cytotoxic capabilities, but are primarily considered to have an important regulatory function via the secretion of large amounts of proor anti-inflammatory cytokines upon activation, thereby resulting in amplification or dampening of the immune response [25]. Due to a lack of specific markers, it is not possible as yet to identify the entire NKT cell population using flow cytometry or immunohistochemistry [25]. In many studies, co-expression of CD3 and CD56 is used to identify NKT cells [26-31]. Although it is likely that the $\mathrm{CD}^{+}{ }^{+} \mathrm{CD} 56^{+}$cell population includes "true" $\mathrm{CD} 1 \mathrm{~d}-$ restricted NKT cells, it has to be taken into account that conventional $\mathrm{T}$ cells have also been reported to express CD56 [32, 33]. Thus, since it is unclear whether all $\mathrm{CD} 3^{+} \mathrm{CD} 6^{+}$cells are $\mathrm{CD} 1 \mathrm{~d}$-restricted, this population is often referred to as "NKT-like". 
In this study, we aimed to characterize the immunophenotype of circulating T cells, NK cells, and NKT-like cells in CRC patients using multiparameter flow cytometry, and to subsequently correlate these immunophenotypes to clinical follow-up data.

\section{Materials and methods}

\section{Study population}

The study population comprised patients diagnosed with CRC who underwent surgical resection of their colorectal tumor at the Leiden University Medical Center (LUMC, the Netherlands) between 2001 and 2007. From these patients, peripheral blood samples were collected within a month prior to surgery. In the present study, patients with histologically proven primary colorectal tumors, Tumor Node Metastasis (TNM) stage 0-IV, surgical R0 resection, and a minimal amount of five million cryopreserved peripheral blood mononuclear cells (PBMCs) were included $(N=87)$. Patients with multiple colorectal tumors at the time of diagnosis or resection were excluded. Patient follow-up was performed until August 2017, with a median follow-up time of 12 years (range $0.1-15.8$ years). Peripheral blood samples obtained from 19 healthy donors (Dept. of Hematology, LUMC) served as controls.

\section{Isolation of peripheral blood mononuclear cells}

PBMCs were isolated by Ficoll-Paque (density $1.077 \mathrm{~g} / \mathrm{ml}$, provided by the apothecary LUMC) density-gradient centrifugation. All PBMC samples were cryopreserved in liquid nitrogen until time of analysis in freezing medium containing 20\% heat-inactivated FCS (Thermo Fisher Scientific, Waltham, MA, USA) and 10\% DMSO (Avantor, Center Valley, PA, USA). Additionally, PBMCs were isolated from the buffy coat of a healthy donor obtained from the Blood Bank at Aarhus University Hospital (Dept. Clinical Immunology, Aarhus University Hospital, Skejby, Denmark) which was used as an internal control in the flow cytometry experiments. After isolation using Histopaque (Sigma-Aldrich, St. Louis, MO, USA) density-gradient centrifugation, these PBMCs were cryopreserved at $-150{ }^{\circ} \mathrm{C}$ until time of use in RPMI-1640 medium (Lonza, Basel, Switzerland) containing 20\% heat-inactivated FCS (GE Healthcare, Little Chalfont, United Kingdom), and 10\% DMSO (Sigma-Aldrich).

\section{Flow cytometry antibody staining}

Extensive immunophenotyping of circulating T cells, NK cells, and NKT-like cells was performed using multiparameter flow cytometry with directly fluorochrome-conjugated mouse mAb (Supplementary Table 1). Briefly, PBMCs were thawed at $37{ }^{\circ} \mathrm{C}$, washed in PBS (Lonza)/10\% FCS (GE Healthcare), and cell count was determined using a NucleoCounter ${ }^{\circledR N C}-250^{\mathrm{TM}}$ (ChemoMetec, Allerod, Denmark) according to the manufacturer's instructions. PBMCs were adjusted to a concentration of $10 \times 10^{6}$ cells $/ \mathrm{ml}$ and blocked for non-specific Ab binding in PBS/0.5\% BSA (Merck Millipore, Billerica, MA, USA)/0.09\% sodium azide buffer (Ampliqon, Odense, Denmark) with 5\% human $\mathrm{AB}$ serum (from a batch of healthy donors obtained from the Blood Bank at Aarhus University Hospital) or $50 \mu \mathrm{g} /$ ml human Ig (Human Ig, CSL Behring, Bern, Switzerland) for $15 \mathrm{~min}$. Three multicolor flow cytometry panels were designed for the identification of circulating T cells, NK cells, and NKT-like cells (Supplementary Table 1). For each flow panel, a cocktail of $\mathrm{Ab}$ was prepared in $\mathrm{BD}$ brilliant stain buffer (BD Biosciences) to prevent aggregation of brilliant violet fluorochromes. PBMCs $\left(0.5 \times 10^{6}\right.$ cells $)$ were incubated with the antibody cocktails in the dark for $30 \mathrm{~min}$ at room temperature (flow panel 1 and 2 ) or at $4{ }^{\circ} \mathrm{C}$ (flow panel 3), as these conditions provided optimal binding for the included $\mathrm{Ab}$ in each panel. To exclude dead cells from the analysis, a live/dead fixable near-infrared dead cell stain kit (Life Technologies, Carlsbad, CA, USA) was included in each staining. After incubation with the Ab cocktails, the cells were washed twice in PBS/ $0.5 \%$ BSA $/ 0.09 \%$ sodium azide buffer. Next, PBMCs were fixed in PBS/ $0.9 \%$ formaldehyde (Sigma-Aldrich) before analysis.

\section{Flow cytometry data analysis}

Samples were analyzed immediately after staining on the LSR Fortessa (BD Biosciences) flow cytometer running FACSDiva $^{\mathrm{TM}}$ software version 8.0 (BD Biosciences). The data set was analyzed using FlowJo software version 10.1 (Tree Star Inc., Ashland, OR, USA). In each experiment, PBMCs derived from the same buffy coat (described above) were included as an internal control. Instrument performance was verified daily using the Cytometer Setup \& Tracking (CS\&T) system (BD Biosciences), applying CS\&T application settings to ensure comparable flow cytometry results over time. Compensation was carried out with CompBeads (BD Biosciences), OneComp eBeads (eBioscience, Inc., San Diego, CA), CompBeads Plus (BD Biosciences), and $\mathrm{ArC}$ reactive beads (Life Technologies) according to the manufacturer's protocol. The threshold for positive staining was determined using unstained- or fluorescence minus one (FMO) controls when necessary [34, 35]. FMO controls were used for CD56, CD158a, and NKG2A in flow panel 1. Since there was no spectral overlap between the fluorochromes brilliant violet 711 (CD158a) and allophycocyanin (NKG2A), FMO controls for CD158a and NKG2A were combined in a fluorescence minus two (FM2) control 
following proper verification. Furthermore, an FMO control for CD56 in flow panel 2 was included. To identify circulating T cells, NK cells, and NKT-like cells, a sequential gating strategy for each flow panel was created based on the buffy coat internal control sample (Supplementary Figs. 1, 2, and 3 ). The expression of phenotypic markers on circulating $T$ cells, NK cells and NKT-like cells was then evaluated by the median fluorescence intensity (MFI) and/or the percentage of positive cells. The markers CD3, CD14, and CD56 were strictly used for gating and not studied in further detail.

\section{Corrections and statistical analyses}

The NKG2A antibody was changed regarding isotype and clone during the flow cytometry experiments due to low quality of a newly ordered $\mathrm{Ab}$ batch. The internal control buffy coat was used to correct for differences in the MFI and percentage of positive lymphocytes regarding NKG2A between the two used Ab clones. Statistical analyses were conducted using SPSS statistical software (IBM SPSS Statistics 23, Chicago, USA). The Mann-Whitney $U$ test was used to compare the age of the CRC patients with the healthy donors. The sex of CRC patients was compared with healthy donors using a Pearson $\chi^{2}$ test. Additionally, independent samples $T$ tests and Mann-Whitney $U$ tests, where appropriate, were used to compare patients with healthy donors and to evaluate differences in patient and tumor characteristics. Furthermore, the Spearman correlation test was used to study the relation of phenotypic markers on different immune cell subsets. Throughout the text, the median percentages or MFI are reported including standard deviations (SD). Kaplan-Meier analyses and log-rank tests were used to investigate and compare survival within patient subgroups. Our primary clinical endpoint was disease-free survival (DFS), which was defined as the time from surgery until recurrence of disease or death, whichever came first, or end of follow-up (censored). Cox regression analysis was used for univariate and multivariate analyses for DFS. We corrected for multiple testing using the Benjamini-Hochberg method, by which adjusted $P$ values were calculated (indicated by $P^{*}$ ) [36]. $P$ - and $P^{*}$ values $\leq 0.05$ were considered statistically significant.

\section{Results}

\section{Patient characteristics}

In total, flow cytometry data of $71 / 87$ (81.6\%) CRC patients could be included in the analysis. Eight samples were excluded due to low viability of the PBMCs $(<50 \%$ viable cells). Additionally, samples from two patients were obtained prior to resection of liver metastases instead of the primary colorectal tumor and, therefore, also excluded from further analysis. Furthermore, four patients were excluded from this study due to a confirmed diagnosis of Lynch syndrome. Finally, two patients were excluded due to pre-surgical chemotherapy before sample collection. Eleven patients included in the study had undergone local radiotherapy prior to the collection of the blood sample. Since local radiotherapy is unlikely to affect the immune system systemically, these patients were not excluded from this study. Table 1 summarizes the clinico-pathological characteristics of the 71 CRC patients included in the analyses, together with 19 healthy donors. When comparing the CRC patients with the healthy donors, no significant difference was observed in relation to sex (Table 1). A trend was observed towards a higher age in the CRC patients compared to the healthy

Table 1 Patient demographics and tumor characteristics

\begin{tabular}{llll}
\hline & CRC patients & \multicolumn{2}{l}{ Healthy donors } \\
\cline { 4 - 4 } & $(N=71)$ & $(N=19)$ & $P$ value \\
\hline Age* & & & 0.06 \\
Mean (years) & 65.6 & 55.6 & \\
Range & $25-85$ & & \\
Sex & & & \\
Female & $32(45.1 \%)$ & & \\
Male & $39(52.6 \%)$ & \\
Tumor location & & & \\
Colon & $59(83.1 \%)$ & & \\
Rectum & $12(16.9 \%)$ & \\
Tumor stage & & \\
Stage 0 & $4(5.6 \%)$ & \\
Stage I & $10(14.1 \%)$ & \\
Stage II & $22(35.2 \%)$ & \\
Stage III & $22(33.8 \%)$ & \\
Stage IV & $8(11.3 \%)$ & \\
Tumor differentiation & & \\
Wrade & \\
Poll/moderate & $55(77.5 \%)$ & \\
Unknown & $13(18.3 \%)$ & \\
Lymph node invasion & $3(4.2 \%)$ & \\
Yes & $30(56.3 \%)$ & \\
No & $40(42.3 \%)$ & \\
Unknown & $1(1.4 \%)$ & \\
Neoadjuvant radiotherapy & \\
Yes & $10(14.1 \%)$ & \\
No & $61(85.9 \%)$ & \\
Adjuvant chemotherapy & \\
Yes & & \\
No & & \\
\hline
\end{tabular}

In this study, the immunophenotype of peripheral blood immune cell profiles was investigated in 71 CRC patients and 19 healthy donors

${ }^{*}$ Age at time of surgery 
donors, which was not statistically significant (Table 1). Flow cytometry panels 1 and 2 (NK cells and NKT-like cells) were investigated in all included 71 CRC patients and 19 healthy donors. Flow cytometry panel 3 (T cells) was investigated in $47 \mathrm{CRC}$ patients and 10 healthy donors.

\section{Increased percentage of circulating regulatory $T$ cells in colorectal cancer patients compared to healthy donors}

In this study, we compared the immunophenotype of circulating T cells $\left(\mathrm{CD}^{+}{ }^{+} \mathrm{CD} 56^{-}\right)$, $\mathrm{NK}$ cells $\left(\mathrm{CD} 3^{-} \mathrm{CD} 56^{+}\right)$, and NKT-like cells $\left(\mathrm{CD}^{+}{ }^{+} \mathrm{CD} 56^{+}\right)$between CRC patients and healthy donors. First of all, the distribution of the different immune cell subsets was studied (Table 2). We hypothesized that CRC patients would present with a general immunocompromised state of circulating immune cells, reflected by a shift in the balance between cytotoxic and regulatory cell subsets. Similar proportions of circulating T cells $\left(P^{*}=0.883\right)$, NK cells $\left(P^{*}=0.768\right)$, and NKT-like cells $\left(P^{*}=0.904\right)$ (\% of total lymphocytes) were observed in CRC patients and healthy donors (Fig. 1a, e, h, respectively). Furthermore, no differences were observed in the distribution of circulating $\mathrm{CD}^{+}\left(P^{*}=0.670\right)$ and $\mathrm{CD}^{+}\left(P^{*}=0.689\right) \mathrm{T}$ cells (\% of T cells) or distribution of circulating CD56 dim $\left(P^{*}=0.197\right)$ and $\mathrm{CD} 56^{\text {bright }}\left(P^{*}=0.196\right)$ NK cell populations (\% of NK cells) (Fig. 1b, c, f, g, respectively). In contrast, CRC patients presented with an increased percentage of circulating CD127 ${ }^{\text {low }} \mathrm{CD} 25^{+} \mathrm{T}_{\text {reg }}\left(P^{*}<0.001\right)(\%$ of $\mathrm{CD}^{+} \mathrm{CD}^{+} \mathrm{T}$ cells) (Fig. 1d) compared to healthy donors.

\section{Reduced expression of natural cytotoxicity receptors on circulating CD56 ${ }^{\mathrm{dim}}$ NK cells and NKT-like cells from colorectal cancer patients compared to healthy donors}

We subsequently evaluated the immunophenotype of circulating NK cells and NKT-like cells in CRC patients compared to healthy donors (Table 2). The percentage of NKp $44^{+}$cells within the CD56 ${ }^{\mathrm{dim}} \mathrm{NK}$ cell subset and NKT-like subset was comparable between CRC patients and healthy donors $\left(P^{*}=0.239\right.$ and $P^{*}=0.941$, respectively) (Fig. 2a, b). In contrast, the expression level (MFI) of NKp44 was decreased in CRC patients on both CD56 ${ }^{\mathrm{dim}}$ NK cells $\left(P^{*}=0.041\right)$ and NKT-like cells $\left(P^{*}=0.025\right)$ compared to healthy donors (Fig. 2d, e). Interestingly, the presence $(P=0.013)$ and expression $(P<0.001)$ of NKp44 on CD56 ${ }^{\text {dim }}$ NK cells and NKT-like cells strongly correlated (Fig. 2c, f). Hence, patients with a low-percentage positive cells or expression level of NKp44 for CD56 ${ }^{\mathrm{dim}} \mathrm{NK}$ cells also had a low percentage positive cells or expression level of NKp44 for NKT-like cells and the other way around. Additionally, we observed a decreased percentage of NKp $46^{+}$ cells within the CD56 ${ }^{\mathrm{dim}} \mathrm{NK}$ cell subset compared to healthy donors $\left(P^{*}=0.031\right)$ (Fig. $2 \mathrm{~g}$ ), whereas in the NKT-like cell population, no statistically significant difference was found, only a trend $\left(P^{*}=0.097\right)$ (Fig. 2 h). In contrast to NKp44, the percentage NKp $46^{+}$cells did not correlate (only a trend) between CD56 $6^{\mathrm{dim}}$ NK cells and NKT-like cells $(P=0.098)$ (Fig. 2i). Furthermore, the expression level of NKp46 was decreased on both CD56 ${ }^{\mathrm{dim}}$ NK cells $\left(P^{*}=0.031\right)$ and NKTlike cells $\left(P^{*}<0.001\right)$ in CRC patients compared to healthy donors (Fig. 2j, k). Expression level of NKp46 strongly correlated on CD56 ${ }^{\mathrm{dim}}$ NK cells and NKT-like cells $(P=0.004)$ (Fig. 21). In contrast to the CD56 ${ }^{\mathrm{dim}} \mathrm{NK}$ cell and NKT-like cell populations, the percentage of positive cells and expression level of NKp44 and NKp46 were not decreased in the CD56 $6^{\text {bright }}$ NK cell population (Table 2). No differences in other phenotypic markers were observed related to NK cells or NKT-like cells between CRC patients and healthy donors (Table 2).

\section{No correlation between distribution of immune cell subsets and immunophenotype of circulating lymphocytes and tumor characteristics}

After discovering different peripheral blood immune cell profiles in CRC patients compared to healthy donors, the relationship with disease stage was investigated. The course of tumor progression entails a series of stages that ultimately leads to the formation of metastases in distant organs. It is hypothesized that the systemic immune system is activated during tumor progression in CRC upon disruption of the basal membrane located underneath the intestinal epithelium which allows tumor cells to grow into surrounding tissue and to enter blood vessels. As such, CRC patients were subdivided according to their TNM at the time of diagnosis into patients without disruption of the basal membrane (stage 0/I, $N=13$ ), and patients with disruption of the basal membrane (stage II/III/IV, $N=58$ ).

No differences were observed in the distribution of immune cell subsets or their immunophenotype between CRC patients with or without disruption of the basal membrane. Furthermore, we did not observe any correlation between the immune cell subset distribution or immunophenotype of circulating lymphocytes and tumor location, lymph-node invasion or tumor differentiation grade (data not shown).

\section{Association between the peripheral blood immune cell profile and disease-free survival of colorectal cancer patients}

We subsequently wondered whether peripheral blood immune cell profiles were associated with clinical outcome in CRC patients. Therefore, survival plots as well 
Table 2 Comparison between peripheral blood immune cell profiles in CRC patients and healthy donors

\begin{tabular}{|c|c|c|c|c|c|c|}
\hline & \multicolumn{2}{|c|}{$\begin{array}{l}\text { Healthy controls } \\
(N=19)\end{array}$} & \multicolumn{2}{|c|}{ CRC patients $(N=71)$} & \multirow[b]{2}{*}{$P$ value } & \multirow[b]{2}{*}{$\begin{array}{l}\text { Corrected } \\
P^{*} \text { value }\end{array}$} \\
\hline & Mean & SD & Mean & SD & & \\
\hline \multicolumn{7}{|l|}{ Subset distribution } \\
\hline T cells $(\%)^{*}$ & 59.4 & 8.2 & 57.5 & 13.2 & $0.669^{\mathrm{T}}$ & 0.883 \\
\hline CD ${ }^{+}$T cells $(\%)^{*}$ & 20.7 & 8.3 & 18.7 & 10.4 & $0.378^{\mathrm{U}}$ & 0.670 \\
\hline$C D 4^{+}$T cells $(\%)^{*}$ & 42.1 & 6.1 & 44.3 & 12.2 & $0.400^{\mathrm{T}}$ & 0.689 \\
\hline$C D 127^{\text {low }} C D 25^{+} T_{\text {reg }}(\%)^{*}$ & 5.5 & 0.5 & 7.7 & 2.4 & $0.000^{\mathrm{U}}$ & 0.000 \\
\hline NK cells $(\%)$ & 12.8 & 5.4 & 15.4 & 8.5 & $0.508^{\mathrm{U}}$ & 0.768 \\
\hline CD56 $6^{\text {dim }} N K$ cells $(\%)$ & 93.4 & 4.2 & 95 & 4.2 & $0.054^{\mathrm{U}}$ & 0.197 \\
\hline CD56 bright $N K$ cells (\%) & 6.6 & 4.2 & 5.1 & 4.2 & $0.057^{\mathrm{U}}$ & 0.196 \\
\hline NKT-like cells (\%) & 4.3 & 2.8 & 6.1 & 6.4 & $0.656^{\mathrm{U}}$ & 0.904 \\
\hline \multicolumn{7}{|l|}{ CD56 ${ }^{\mathrm{dim}} \mathrm{NK}$ cells } \\
\hline$C D 16^{+}(\%)$ & 85.3 & 6.1 & 83.7 & 10.2 & $0.909^{\mathrm{U}}$ & 0.989 \\
\hline$C D 158 a^{+}(\%)$ & 35.2 & 17.1 & 31.9 & 16.9 & $0.477^{\mathrm{U}}$ & 0.739 \\
\hline$C D 158 b^{+}(\%)$ & 37 & 11.4 & 37.5 & 14.7 & $0.786^{\mathrm{U}}$ & 0.937 \\
\hline$N K G 2 A^{+}(\%)$ & 45.6 & 19.3 & 43.4 & 19 & $0.656^{\mathrm{T}}$ & 0.884 \\
\hline$N K G 2 A^{+}(M F I)$ & 6398 & 2138 & 7368 & 2459 & $0.275^{\mathrm{U}}$ & 0.533 \\
\hline$N K G 2 C^{+}(\%)$ & 13.7 & 13 & 16.2 & 17.9 & $0.909^{\mathrm{U}}$ & 0.972 \\
\hline$N K G 2 C^{+}(M F I)$ & 2506 & 2797 & 2965 & 3094 & $0.213^{\mathrm{U}}$ & 0.440 \\
\hline CD161 (MFI) & 3111 & 804 & 3057 & 1130 & $0.816^{\mathrm{T}}$ & 0.903 \\
\hline$C D 8^{+}(\%)$ & 34.3 & 14.3 & 31.5 & 14.4 & $0.467^{\mathrm{U}}$ & 0.742 \\
\hline$C D 8^{+}(M F I)$ & 3481 & 774 & 3067 & 1159 & $0.067^{\mathrm{U}}$ & 0.208 \\
\hline DNAM-1 (MFI) & 560 & 106 & 548 & 146 & $0.741^{\mathrm{T}}$ & 0.919 \\
\hline$N K G 2 D^{+}(\%)$ & 89.9 & 4.4 & 91.4 & 4.9 & $0.134^{\mathrm{U}}$ & 0.346 \\
\hline$N K G 2 D^{+}(M F I)$ & 3600 & 1108 & 3429 & 1113 & $0.554^{\mathrm{T}}$ & 0.818 \\
\hline NKp30 (MFI) & 1960 & 752 & 1630 & 900 & $0.052^{\mathrm{U}}$ & 0.202 \\
\hline$N K p 44^{+}(\%)$ & 0.7 & 0.6 & 0.6 & 0.6 & $0.081^{\mathrm{U}}$ & 0.239 \\
\hline NKp44 (MFI) & 131 & 13 & 115 & 26 & $0.002^{\mathrm{U}}$ & 0.041 \\
\hline$N K p 46^{+}(\%)$ & 48.7 & 18 & 34.7 & 16.9 & $0.002^{\mathrm{T}}$ & 0.031 \\
\hline NKp46 (MFI) & 732 & 345 & 478 & 271 & $0.003^{\mathrm{U}}$ & 0.031 \\
\hline \multicolumn{7}{|l|}{ CD56 ${ }^{\text {bright }} \mathrm{NK}$ cells } \\
\hline $\mathrm{CD}^{+} 6^{+}(\%)$ & 3 & 2.8 & 2.5 & 1.8 & $0.415^{\mathrm{U}}$ & 0.695 \\
\hline$C D 158 a^{+}(\%)$ & 6.6 & 4.2 & 7 & 4.8 & $0.793^{\mathrm{U}}$ & 0.928 \\
\hline$C D 158 b^{+}(\%)$ & 6.4 & 3 & 8.6 & 5.5 & $0.097^{\mathrm{U}}$ & 0.273 \\
\hline$N K G 2 A^{+}(\%)$ & 6.6 & 4.6 & 4.5 & 3.3 & $0.044^{\mathrm{U}}$ & 0.210 \\
\hline$N K G 2 A^{+}(M F I)$ & 17,020 & 7986 & 19,052 & 5829 & $0.165^{\mathrm{U}}$ & 0.365 \\
\hline$N K G 2 C^{+}(\%)$ & 1.9 & 2.2 & 1.2 & 1.1 & $0.145^{\mathrm{U}}$ & 0.333 \\
\hline$N K G 2 C^{+}(M F I)$ & 1760 & 967 & 3038 & 3831 & $0.017^{\mathrm{U}}$ & 0.105 \\
\hline CD161 (MFI) & 2128 & 568 & 1767 & 578 & $0.012^{\mathrm{U}}$ & 0.093 \\
\hline$C D 8^{+}(\%)$ & 2.4 & 1.6 & 1.8 & 1.7 & $0.044^{\mathrm{U}}$ & 0.195 \\
\hline$C D 8^{+}(M F I)$ & 2951 & 886 & 3098 & 1318 & $0.945^{\mathrm{U}}$ & 0.977 \\
\hline DNAM-1 (MFI) & 765 & 130 & 782 & 161 & $0.675^{\mathrm{T}}$ & 0.872 \\
\hline$N K G 2 D^{+}(\%)$ & 6.2 & 4.1 & 4.7 & 3.7 & $0.062^{\mathrm{U}}$ & 0.202 \\
\hline$N K G 2 D^{+}(M F I)$ & 5321 & 1354 & 6210 & 1837 & $0.037^{\mathrm{U}}$ & 0.191 \\
\hline NKp30 (MFI) & 2145 & 418 & 2413 & 769 & $0.048^{\mathrm{T}}$ & 0.198 \\
\hline$N K p 44^{+}(\%)$ & 2 & 1.5 & 1.3 & 1.2 & $0.024^{\mathrm{U}}$ & 0.135 \\
\hline NKp44 (MFI) & 252 & 49 & 236 & 78 & $0.099^{\mathrm{U}}$ & 0.267 \\
\hline$N K p 46^{+}(\%)$ & 86.1 & 8.1 & 80.7 & 14.3 & $0.135^{\mathrm{U}}$ & 0.322 \\
\hline$N K p 46(M F I)$ & 2343 & 613 & 2090 & 812 & $0.211^{\mathrm{T}}$ & 0.451 \\
\hline
\end{tabular}


Table 2 (continued)

\begin{tabular}{|c|c|c|c|c|c|c|}
\hline & \multicolumn{2}{|c|}{$\begin{array}{l}\text { Healthy controls } \\
(N=19)\end{array}$} & \multicolumn{2}{|c|}{ CRC patients $(N=71)$} & \multirow[b]{2}{*}{$P$ value } & \multirow[b]{2}{*}{$\begin{array}{l}\text { Corrected } \\
P^{*} \text { value }\end{array}$} \\
\hline & Mean & SD & Mean & SD & & \\
\hline \multicolumn{7}{|l|}{ NKT-like cells } \\
\hline $\mathrm{CD} 16^{+}(\%)$ & 35.6 & 17.6 & 24.6 & 13.7 & $0.013^{\mathrm{U}}$ & 0.090 \\
\hline$C D 158 a^{+}(\%)$ & 12 & 12.9 & 9.4 & 9.8 & $0.957^{\mathrm{U}}$ & 0.973 \\
\hline$C D 158 b^{+}(\%)$ & 18.8 & 19.2 & 19.2 & 19.2 & $0.793^{\mathrm{U}}$ & 0.910 \\
\hline$N K G 2 A^{+}(\%)$ & 31.9 & 25.4 & 28.3 & 21 & $0.692^{\mathrm{U}}$ & 0.876 \\
\hline$N K G 2 A^{+}(M F I)$ & 4529 & 4416 & 3444 & 3757 & $0.604^{\mathrm{U}}$ & 0.851 \\
\hline$N K G 2 C^{+}(\%)$ & 15 & 15.6 & 14.2 & 13.3 & $0.909^{\mathrm{U}}$ & 0.955 \\
\hline$N K G 2 C^{+}(M F I)$ & 2308 & 2256 & 3205 & 3300 & $0.283^{\mathrm{U}}$ & 0.532 \\
\hline CD161 (MFI) & 4509 & 4407 & 4445 & 5434 & $0.452^{\mathrm{U}}$ & 0.737 \\
\hline$C D 8^{+}(\%)$ & 64.1 & 16.9 & 70.4 & 17.9 & $0.134^{\mathrm{U}}$ & 0.332 \\
\hline$C D 8^{+}(M F I)$ & 11,870 & 6011 & 11,673 & 5556 & $0.968^{\mathrm{U}}$ & 0.968 \\
\hline DNAM-1 (MFI) & 847 & 211 & 766 & 279 & $0.238^{\mathrm{T}}$ & 0.476 \\
\hline$N K G 2 D^{+}(\%)$ & 85.4 & 14.5 & 88.6 & 10.7 & $0.345^{\mathrm{U}}$ & 0.629 \\
\hline$N K G 2 D^{+}(M F I)$ & 4730 & 1589 & 4995 & 2041 & $0.602^{\mathrm{T}}$ & 0.868 \\
\hline NKp30 (MFI) & 217 & 70.1 & 250 & 136 & $0.797^{\mathrm{U}}$ & 0.898 \\
\hline $\mathrm{NKp}_{4} 4^{+}(\%)$ & 1.4 & 1 & 1.4 & 1.2 & $0.774^{\mathrm{U}}$ & 0.941 \\
\hline$N K p 44(M F I)$ & 134 & 17 & 120 & 33 & $0.002^{\mathrm{U}}$ & 0.025 \\
\hline$N K p 46^{+}(\%)$ & 5.4 & 1.9 & 4.6 & 2.8 & $0.011^{\mathrm{U}}$ & 0.097 \\
\hline$N K p 46(M F I)$ & 112 & 53 & 61 & 47 & $0.000^{\mathrm{U}}$ & 0.000 \\
\hline
\end{tabular}

The distribution of circulating immune cell subsets and their immunophenotype was compared between CRC patients $(N=71)$ and healthy donors $(N=19)$. $P$ values were corrected for multiple testing using the Benjamini-Hochberg method, by which adjusted $P$ values were calculated (indicated by $\left.P^{*}\right) . P^{*}$ values $\leq 0.05$ were considered statistically significant and are indicated in bold

${ }^{*} \mathrm{~T}$ cells were investigated in 10 healthy donors and $47 \mathrm{CRC}$ patients

${ }^{\mathrm{T}}$ Independent samples $T$ test

${ }^{\mathrm{U}}$ Mann-Whitney $U$ test

as univariate and multivariate analyses were generated for stage II and III CRC patients at risk of developing metastases. The median percentage of positive cells or expression level of the immunophenotypic marker was used as cutoff. Kaplan-Meier plots and log-rank tests revealed that CRC patients with above-median $(>6.9 \%, N=12)$ percentage of circulating $\mathrm{T}_{\text {reg }}$ showed a trend towards shorter DFS compared to CRC patients with below-median $(N=13)$ percentage $(P=0.062)$ (Fig. 3a), with a hazard ratio (HR) of 2.551 (95\% confidence interval (CI) $0.921-7.069, P=0.072$ ). Furthermore, survival analyses revealed that above median (MFI $>2327, N=24)$ expression of NKp30 on CD56 $6^{\text {bright }}$ NK cells $(P=0.042)$ and above-median percentage $(>20.3 \%, N=24)$ of CD16 ${ }^{+}$NKT-like cells $(P<0.001)$ were associated with short DFS in CRC patients, with a HR of 2.143 (95\% CI 1.009-4.551, $P=0.047)$ and 4.697 (95\% CI 2.046-10.783, $P<0.001$ ), respectively (Fig. 3b;3c). In contrast, CRC patients with above-median $(>5.1 \%, N=24)$ percentage of inhibitory receptor CD158a ${ }^{+}$NKT-like cells showed a trend towards shorter DFS compared to patients with below-median $(N=25)$ percentage $(P=0.068)$ (Fig. 3d) with a HR of 1.969 (95\% CI $0.937-4.136, P=0.074)$. A multivariate analysis was performed for DFS in CRC patients which revealed that above-median percentage of activating receptor $\mathrm{CD} 16^{+}$NKT-like cells (HR 4.192, 95\% CI 1.578-11.137, $P=0.004)$ remained significantly associated with shorter DFS in CRC patients when corrected for age, sex, tumor stage and lymph-node invasion (Table 3 ). Thus, the presence of CD16 on circulating NKT-like cells may be a novel prognostic biomarker candidate for clinical outcome of CRC patients. No other correlations between immunophenotype and DFS were observed (Supplementary Table 2).

\section{Discussion}

Recently, a new scoring system based on the immune profile in the tumor area, the 'immunoscore', has shown to be a strong prognostic biomarker in CRC [37-41]. High density 

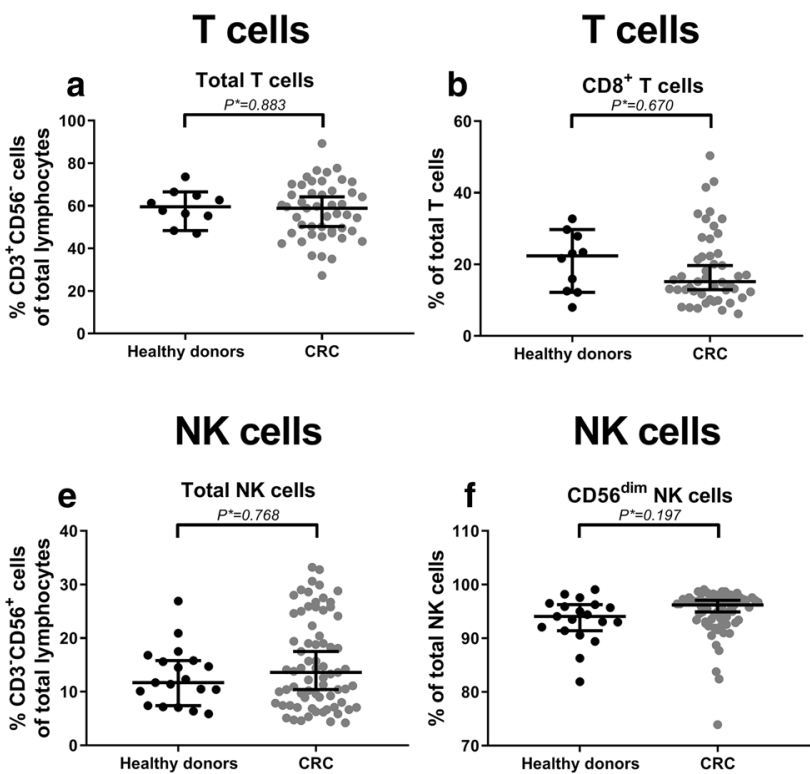

Fig. 1 The peripheral blood immune cell subset distribution in CRC patients compared to healthy donors. The distribution of circulating immune cell subsets was compared between CRC patients (grey dots) and healthy donors (black dots). a The total percentage of T cells (\% $\mathrm{CD}^{+}{ }^{+} \mathrm{CD} 56^{-}$cells of total lymphocytes). b Percentage of $\mathrm{CD}^{+} \mathrm{T}$ cells (\% of total $\mathrm{T}$ cells). c Percentage of $\mathrm{CD}^{+} \mathrm{T}$ cells (\% of total $\mathrm{T}$ cells). d Percentage of $\mathrm{T}_{\text {reg }}\left(\%\right.$ of $\mathrm{CD}^{+} \mathrm{CD}^{+} \mathrm{T}$ cells). e The total

of $\mathrm{CD}^{+}$and $\mathrm{CD}^{+}$tumor-infiltrating lymphocytes was reported to correlate with good clinical outcome in CRC [37, 39-41]. We hypothesized that the distribution and phenotype of circulating immune cell subsets may reflect the local immune response in the TME, thereby providing potentially important information regarding disease progression and therapeutic decision making in CRC. To elucidate the role of the peripheral blood immune system in tumor progression and metastasis in CRC, this study aimed to characterize the distribution and immunophenotype of circulating $\mathrm{T}$ cells, NK cells, and NKT-like cells in CRC patients. These peripheral blood immune cell profiles were subsequently correlated to clinical follow-up data.

We first demonstrated that CRC patients present with alterations in peripheral blood immune subset distribution. We observed a significant increase in the percentage of circulating $\mathrm{T}_{\text {reg }}$ in CRC patients compared to healthy donors. This observation is in line with other studies $[42,43,6]$, and suggests tumor escape in CRC by increasing $T_{\text {reg }}$ which are known to suppress the immune system and, thereby, may support tumor progression using a plethora of different mechanisms $[44,45]$.

Additionally, we demonstrated that CRC patients present with an altered immunophenotype of circulating CD56 $6^{\mathrm{dim}}$ NK cells compared to healthy donors, characterized by reduced expression of the NCRs NKp44 and NKp46. These findings are consistent with previous studies that showed
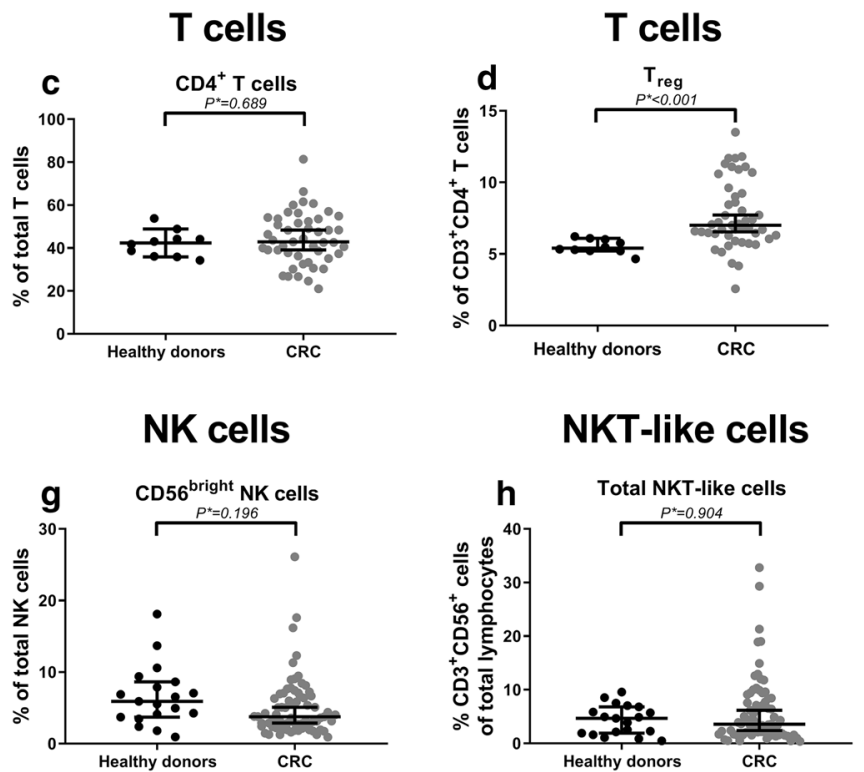

percentage of NK cells (\% $\mathrm{CD}^{-} \mathrm{CD} 56^{+}$cells of total lymphocytes). $\mathbf{f}$ Percentage of CD56 ${ }^{\text {dim }}$ NK cells (\% of total NK cells). g Percentage of CD56 $6^{\text {bright }} \mathrm{NK}$ cells ( $\%$ of total NK cells). h The total percentage of NKT-like cells (\% $\mathrm{CD}^{+} \mathrm{CD} 56^{+}$cells of total lymphocytes). The bars show median percentage of the respective immune cell subset including $95 \% \mathrm{CI}$

a reduced number of activating receptor (e.g., NKG2D, NKp30, NKp46, and DNAM-1)-positive NK cells in peripheral blood of patients with CRC [4, 5]. Additionally, NK cells with downregulated activating receptors showed impaired IFN- $\gamma$ secretion and degranulation upon activation, thereby implying impaired function [4]. These studies did, however, not discriminate between the two major subpopulations of NK cells, namely CD56 ${ }^{\mathrm{dim}}$ and CD $56^{\text {bright }} \mathrm{NK}$ cells, which are known to differ in phenotype as well as function $[18,19]$. Whereas CD56 ${ }^{\mathrm{dim}} \mathrm{NK}$ cells have the potential to kill tumor cells, CD56 ${ }^{\text {bright }} \mathrm{NK}$ cells primarily produce large amounts of cytokines [18, 19]. We showed that circulating CD56 ${ }^{\mathrm{dim}} \mathrm{NK}$ cells were phenotypically altered in CRC patients, whereas CD56 ${ }^{\text {bright }}$ NK cells were not, suggesting that this NK cell subset, involved in cytokine production, is phenotypically, and thereby probably also functionally, not altered in CRC patients. This implicates different roles of CD56 ${ }^{\mathrm{dim}}$ and CD56 $6^{\text {bright }} \mathrm{NK}$ cells in cancer progression, thereby emphasizing the need to discriminate between these NK cell subsets in future studies. Furthermore, we also showed downregulation of the NCRs NKp44 and NKp46 on circulating NKT-like cells in CRC patients compared to healthy donors. In contrast to NK cells, the immunophenotype of circulating NKT cells (in both healthy donors and cancer patients) is not well defined due to the lack of specific markers to identify this immune cell subset. To our knowledge, only one study reported on the immunophenotype 
CD56 $^{\text {dim }}$ NK cells
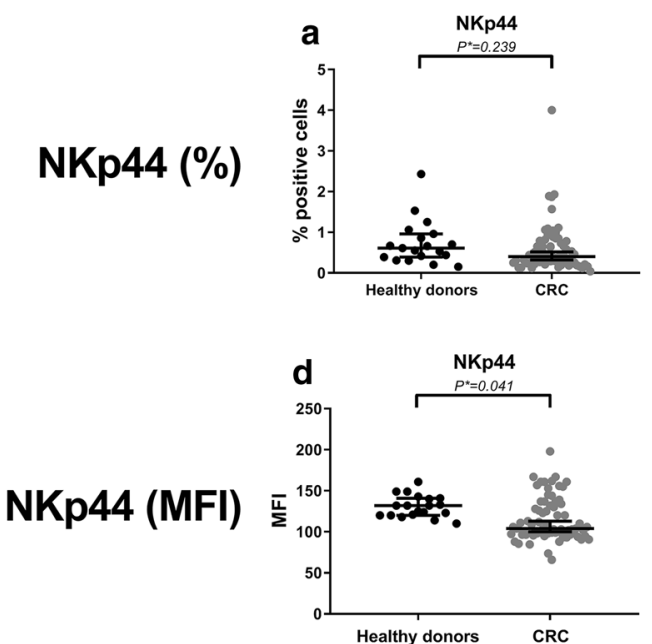

Healthy donors $\quad$ CRC

NKp46 (\%)
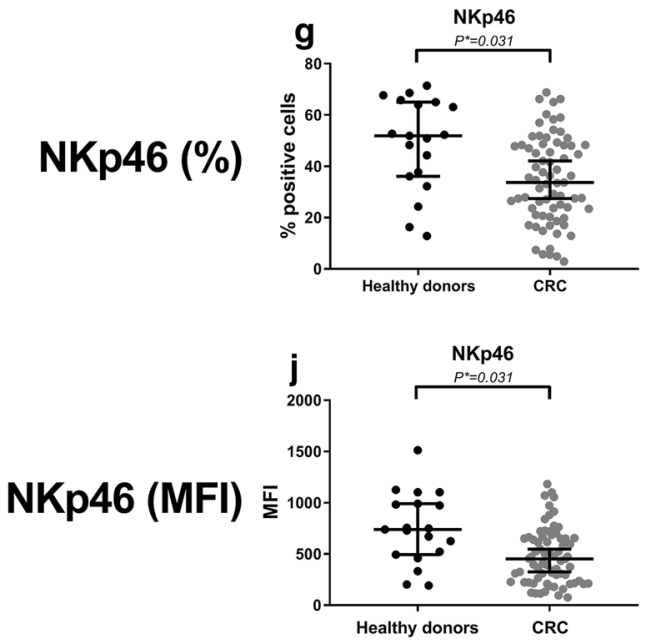

NKT-like cells
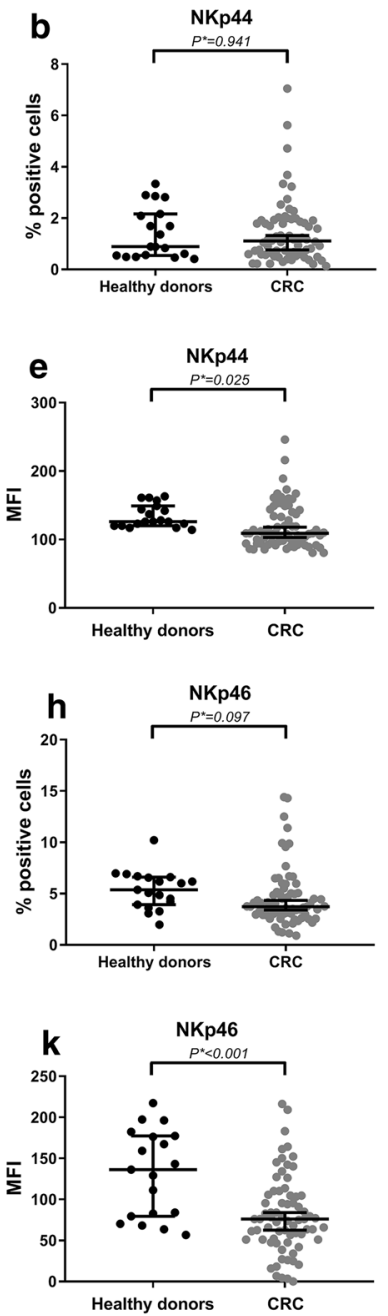

Correlation
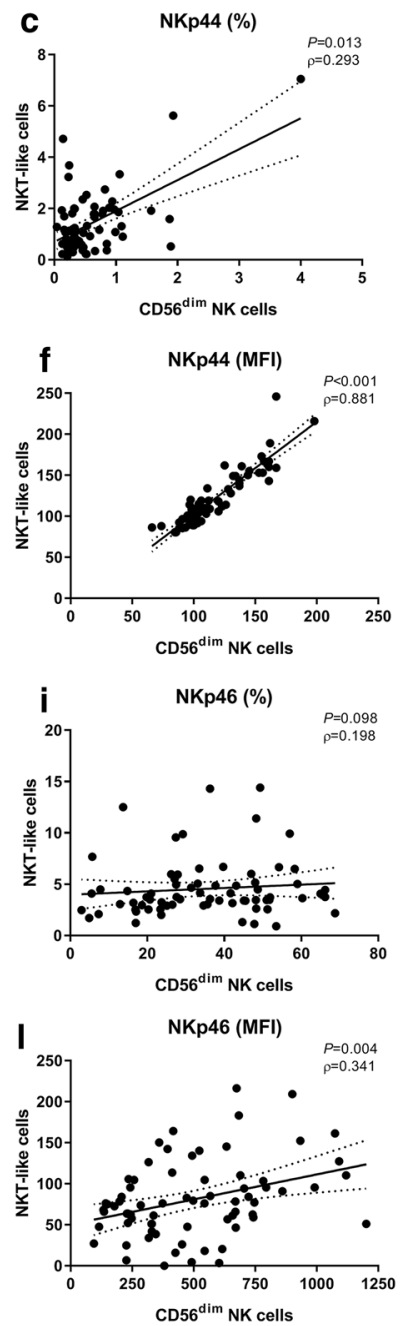

Fig. 2 The peripheral blood immunophenotype of CD56 ${ }^{\mathrm{dim}}$ NK cells and NKT-like cells in CRC patients compared to healthy donors. The peripheral blood immune cell profile was compared between CRC patients (grey dots) and healthy donors (black dots). a The percentage of NKp44 $4^{+} \mathrm{CD} 56^{\text {dim }} \mathrm{NK}$ cells. b Percentage of NKp44 ${ }^{+}$ NKT-like cells. c Correlation between the percentage of $\mathrm{NKp} 44^{+}$ CD56 ${ }^{\text {dim }}$ NK cells and NKT-like cells. $\mathbf{d}$ Expression level of NKp44 on CD56 ${ }^{\mathrm{dim}}$ NK cells. e Expression level of NKp44 on NKT-like cells. f Correlation between expression level of NKp44 on CD56 ${ }^{\text {dim }}$

of circulating NKT-like cells in CRC. This study showed significantly lower numbers of circulating NKG2D ${ }^{+}$NKTlike cells in CRC patients with metastatic disease compared to healthy donors [46]. Our results suggest that presence of a tumor affects expression levels of NKp44 and NKp46 receptors on both CD56 ${ }^{\mathrm{dim}}$ NK cells and NKT-like cells. Over the years, many studies have focused on the effects of a tumor on NK cell function. For instance, NK cells in the TME adapt to survive hypoxic stress by upregulating hypoxia-inducible factor (HIF)- $1 \alpha$ which is associated with
NK cells and NKT-like cells. g Percentage of NKp46 ${ }^{+}$CD56 $6^{\mathrm{dim}}$ NK cells. h Percentage of NKp $46^{+}$NKT-like cells. i Correlation between the percentage of $\mathrm{NKp} 46^{+} \mathrm{CD} 56^{\mathrm{dim}} \mathrm{NK}$ cells and NKT-like cells. $\mathbf{j}$ Expression level of NKp46 on CD56 ${ }^{\mathrm{dim}} \mathrm{NK}$ cells $\mathbf{k}$ Expression level of NKp46 on NKT-like cells. I Correlation between expression level of NKp46 on CD56 ${ }^{\text {dim }}$ NK cells and NKT-like cells. The bars show median percentage or expression level of the respective immunophenotypic marker including $95 \% \mathrm{CI}$

impaired upregulation of NKp44 and NKp46 in response to activating cytokines such as IL-2, IL-12, IL-15, and IL-21 [47]. Furthermore, immune cells and fibroblasts in the TME may produce immunosuppressive cytokines and signal molecules that downregulate [48-50] or prevent IL-2-induced upregulation [51, 52] of NCRs on NK cells. Furthermore, tumor cells may induce downregulation of NCRs on NK cells as a response to hypoxic stress via prostaglandin E2 production or lactate release $[53,54]$. Finally, tumor cells may alter the function of NK cells via overexpression of 
Fig. 3 Relationship between the immune subset distribution and immunophenotype of circulating lymphocyte subsets with DFS of CRC patients. DFS curves are shown for stage II and III CRC patients $(N=49)$ at risk for development of metastases. Stratifications were based on the median percentage of positive cells or expression level of the respective immunophenotypic marker. a The percentage of $\mathrm{T}_{\text {reg }}\left(\% \mathrm{CD}^{+} \mathrm{CD}^{+} \mathrm{T}\right.$ cells $)$. b NKp30 expression level on CD56 ${ }^{\text {bright }}$ NK cells. c Percentage of $\mathrm{CD}_{16}{ }^{+}$circulating NKTlike cells and, $\mathbf{d}$ Percentage of CD158a ${ }^{+}$NKT-like cells. "This marker was only studied in 25 CRC patients at risk for development of metastasis (stage II and III)
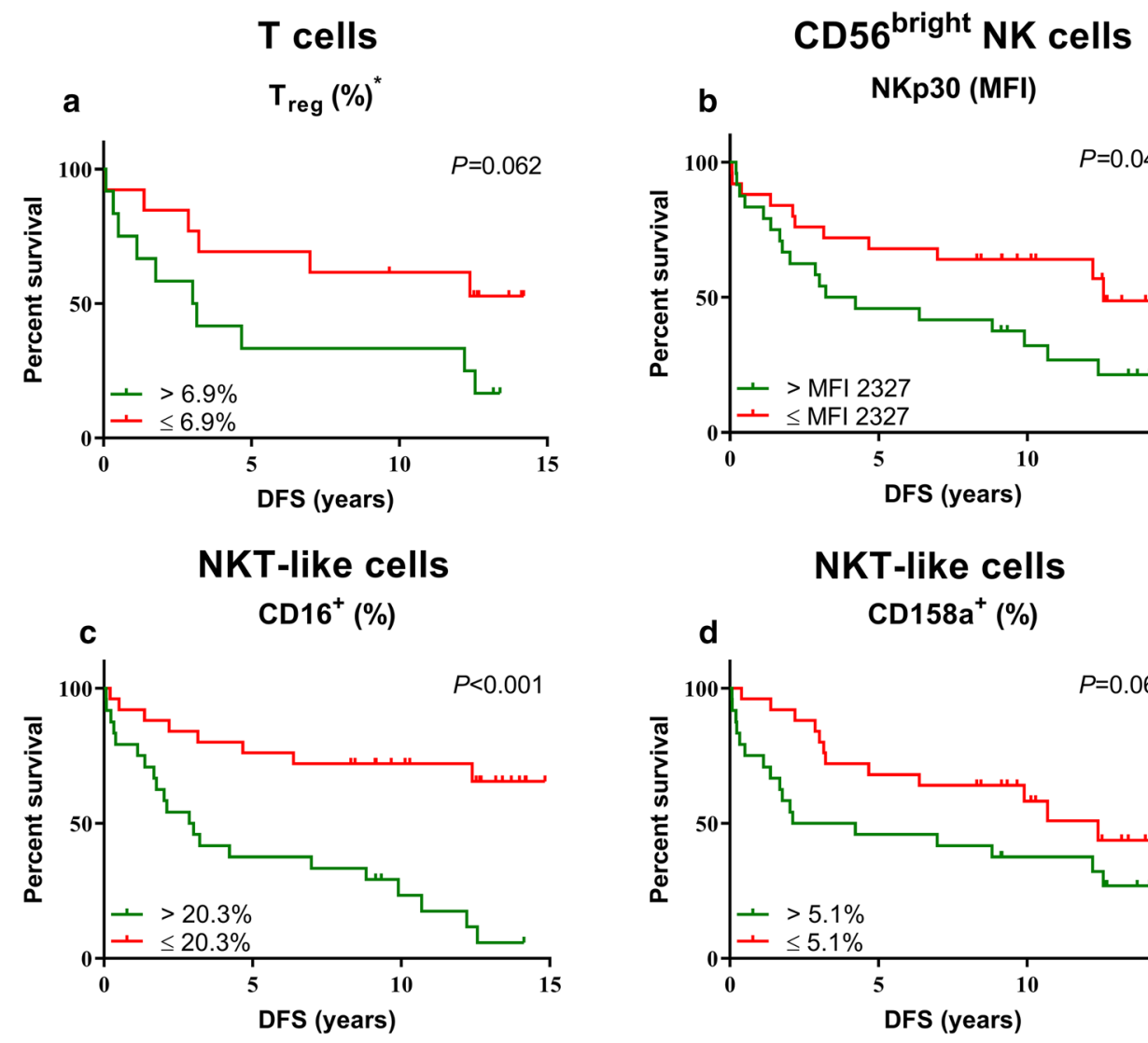

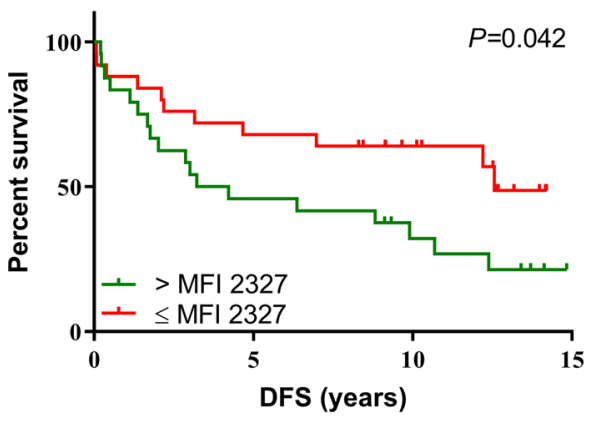

NKT-like cells

CD158a ${ }^{+}(\%)$

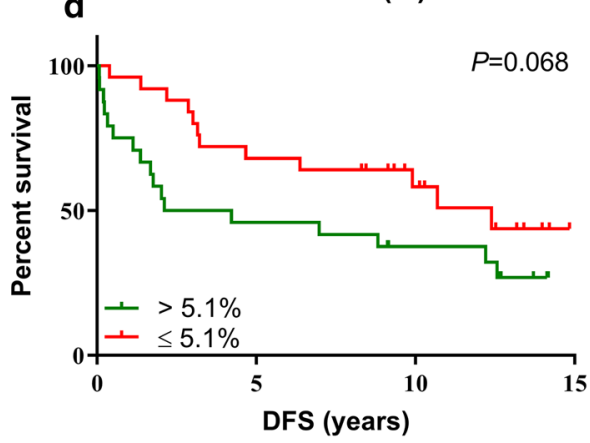

NK cell ligands. For instance, overexpression of proliferating cell nuclear antigen (PCNA) by tumor cells impaired NKp44-mediated NK cell attack in an in vitro model [55, 56]. Whether PCNA also actively downregulates the NKp44 receptor on NK cells is not clear and requires additional research. In conclusion, we observed reduced expression of the NCRs NKp44 and NKp46 on circulating CD56 ${ }^{\mathrm{dim}} \mathrm{NK}$ cells and NKT-like cells in CRC patients, which may be caused by the presence of the tumor via various mechanisms, resulting in functional impairment in these subsets, thereby promoting tumor escape.

Furthermore, we addressed the question whether the peripheral blood immune cell profile in CRC patients was related to tumor stage. Although the peripheral blood immune cell profile was clearly altered in CRC patients as compared to healthy controls, no major shift in the distribution of PBMC subsets was observed in relation with tumor stage of CRC patients. Hence, differences in the peripheral blood immune cell profile were mainly related to the fact that these patients had a colorectal tumor rather than to tumor stage. We did, however, observe a relationship between the immune subset distribution and phenotype of circulating PBMCs and clinical outcome. This suggests that circulating immune cell profiles have prognostic value (i.e., biomarker candidates) for the identification of patients with low tumor grades with a high risk of developing metastatic disease. In general, it is hypothesized that decreased percentages of cytotoxic immune cell subsets or expression levels of activating receptors and increased percentages of regulatory immune cell subsets or expression levels of inhibitory receptors represent an immunocompromised state of the immune system and would therefore be correlated with shorter DFS in CRC patients [57, 58, 4]. In line with this hypothesis, our results revealed that CRC patients with high numbers of circulating $\mathrm{T}_{\text {reg }}$ showed a trend towards shorter DFS compared to patients with low numbers of circulating $\mathrm{T}_{\text {reg }}$, an association also observed by others. For instance, an association was reported between $\mathrm{T}_{\text {reg }}$-mediated suppression of tumor-specific $\mathrm{CD} 4^{+} \mathrm{T}$ cells prior to surgery and tumor recurrence in CRC patients at 12 months [59], whereas FOLFIRI (levo-leucovorin, 5-fluorouracil, irinotexan)- bevacizumab therapy of metastatic CRC patients was associated with better clinical outcome, but also with reduced numbers of circulating $\mathrm{T}_{\mathrm{reg}}[60,61]$. Additionally, in line with our hypothesis, patients with a high percentage of inhibitory receptor $\mathrm{CD} 158 \mathrm{a}^{+}$circulating NKT-like cells showed a trend towards shorter DFS. Since the CD158a receptor recognizes HLA class I molecules, it would be interesting to study HLA class I tumor cell expression in primary colorectal tumors to investigate whether there is an association with the presence of circulating CD158 $\mathrm{a}^{+}$NKT-like immune cells. In contrast with the hypothesis, we observed a statistically significant 
Table 3 Univariate and multivariate analyses for DFS of CRC patients

\begin{tabular}{|c|c|c|c|c|c|c|}
\hline \multirow[t]{2}{*}{ Factor } & \multicolumn{3}{|c|}{ Univariate analysis } & \multicolumn{3}{|c|}{ Multivariate analysis** } \\
\hline & $P$ value & HR & $95 \% \mathrm{CI}$ & $P$ value & HR & $95 \% \mathrm{CI}$ \\
\hline Age $^{*}$ & 0.053 & 1.036 & $0.999-1.075$ & & & \\
\hline \multicolumn{7}{|l|}{ Sex } \\
\hline Female & & Ref. & & & & \\
\hline Male & 0.085 & 1.942 & $0.912-4.136$ & & & \\
\hline \multicolumn{7}{|l|}{ Tumor type } \\
\hline Colon & & Ref. & & & & \\
\hline Rectum & 0.571 & 1.299 & $0.526-3.211$ & & & \\
\hline \multicolumn{7}{|l|}{ Tumor stage } \\
\hline Stage II & & Ref. & & & & \\
\hline Stage III & 0.006 & 2.946 & $1.354-6.412$ & & & \\
\hline \multicolumn{7}{|c|}{ Tumor differentiation grade } \\
\hline Well/moderate & & Ref. & & & & \\
\hline Poor & 0.885 & 0.924 & $0.320-2.669$ & & & \\
\hline \multicolumn{7}{|c|}{ Lymph node invasion } \\
\hline No & & Ref. & & & & \\
\hline Yes & 0.010 & 2.825 & $1.289-6.193$ & & & \\
\hline \multicolumn{7}{|l|}{$\mathrm{T}_{\text {reg }}(\%)^{* * *}$} \\
\hline$\leq 6.9 \%$ & & Ref. & & & Ref. & \\
\hline$>6.9 \%$ & 0.072 & 2.551 & $0.921-7.069$ & 0.119 & 3.142 & $0.744-13.273$ \\
\hline \multicolumn{7}{|c|}{ NKp30 CD56 ${ }^{\text {bright }} \mathrm{NK}$ cells (MFI) } \\
\hline$\leq$ MFI 2327 & & Ref. & & & Ref. & \\
\hline > MFI 2327 & 0.047 & 2.143 & $1.009-4.551$ & 0.169 & 1.752 & $0.788-3.893$ \\
\hline \multicolumn{7}{|c|}{$\mathrm{CD} 16^{+}$NKT-like cells $(\%)$} \\
\hline$\leq 20.3 \%$ & & Ref. & & & Ref. & \\
\hline$>20.3 \%$ & $<0.001$ & 4.697 & $2.046-10.783$ & 0.004 & 4.192 & $1.578-11.137$ \\
\hline \multicolumn{7}{|c|}{$\mathrm{CD} 158 \mathrm{a}^{+}$NKT-like cells $(\%)$} \\
\hline$\leq 5.1 \%$ & & Ref. & & & Ref. & \\
\hline$>5.1 \%$ & 0.074 & 1.969 & $0.937-4.136$ & 0.134 & 1.803 & $0.834-3.897$ \\
\hline
\end{tabular}

Univariate and multivariate analyses for DFS were generated for stage II and III CRC patients $(N=49)$ at risk for development of metastases. The median percentage of positive cells or median expression level was used as a cutoff $[\leq$ median $(N=25)$ and $>$ median $(N=24)]$. $P$ values, HRs, and their CIs were estimated from a Cox proportional hazard regression model, in which the first category was used as reference group. Statistically significant $P$ values are indicated in bold

Ref. reference group

*Age at time of surgery

${ }^{* *}$ Corrected for age, sex, tumor stage and lymph node invasion

**** This marker was only studied in 25 CRC patients at risk for development of metastasis (stage II and III) association between a high expression level of activating receptor NKp30 on circulating CD56 ${ }^{\text {bright }} \mathrm{NK}$ cells and a high percentage of CD16 ${ }^{+}$circulating NKT-like cells and short DFS in CRC patients. A multivariate analysis revealed that the latter, high percentage of $\mathrm{CD} 16^{+}$NKT-like cells, was even independently associated with shorter DFS in CRC patients. From these observations, it might be deduced that the NKp30 and CD16 receptors are activated during the course of tumor cell dissemination. The exact role of the NKp30 and CD16 receptors in the process of dissemination in CRC patients has yet to be elucidated. Possibly, the status of these receptors in patients with poor clinical outcome might affect the tumor immune response, thus acting as an active selection mechanism by which tumor cells escape immune-mediated destruction. In that case, it would, for instance, be likely that ligands for these receptors on tumor cells are downregulated.

In conclusion, we demonstrated profound differences in subset distribution and immunophenotype of PBMCs in CRC patients compared to healthy donors, characterized by an increased percentage of $\mathrm{T}_{\text {reg }}$, and reduced expression of NCRs NKp44 and NKp46 on both CD56 ${ }^{\mathrm{dim}}$ NK cells and NKT-like 
cells. Additionally, a multivariate analysis revealed that abovemedian percentage of $\mathrm{CD} 16^{+}$NKT-like cells was independently associated with shorter DFS in CRC patients. These findings highlight the potential use of circulating lymphocyte subsets as prognostic biomarkers in CRC and contribute to better insight into the role of systemic immune profiles in tumor progression.

Acknowledgements We thank Ronald van Vlierberghe, Rob Keyzer, Geeske Dekker-Ensink (Department of Surgery, LUMC), Camilla Darum Sørensen (Department of Biomedicine, Aarhus University), and Arantza Sarasqueta (Department of Pathology, LUMC) for their contribution to this study. Specifically, we thank the FACS Core Facility of Aarhus University for their help and advice regarding the setup of protocols and analyzing data in flow cytometry, and Nelleke Duinkerken (Department of Hematology, LUMC) for providing PBMC samples from healthy donors.

Author contributions Daniëlle Krijgsman, Natasja L. de Vries, Anni Skovbo, Morten N. Andersen, Marianne Hokland and Peter J.K. Kuppen designed the experiments. Anni Skovbo contributed to sample preparation. Daniëlle Krijgsman and Natasja L. de Vries carried out the experiments, analyzed the data and wrote the manuscript. Esther Bastiaannet verified the statistical methods. All authors provided critical feedback and contributed to the final manuscript. Marianne Hokland and Peter J.K. Kuppen supervised the project.

Funding This project was supported by grants from the European Commission (Erasmus Plus Programme, ET 2020), Leiden University Fund (LUF International Study Fund (LISF)), Leiden University Medical Center (DOO Internationalization scholarship), Kræftfonden (Marianne Hokland) and from the Prof E.L. Noach award (Natasja L. de Vries).

\section{Compliance with ethical standards}

Conflict of interest The authors declare that they have no conflict of interest.

Ethical approval All materials were obtained after approval by the Medical Ethical Committee of the LUMC (P000.193). All procedures performed in this study were in accordance with the ethical standards of the Dutch law ("WMO", medical research involving human subjects act), the Danish law ("LBK" nr. 1083, $15^{\text {th }}$ September 2017), and with the 1964 Helsinki Declaration and its later amendments or comparable ethical standards.

Informed consent All CRC patients and healthy donors included in this study agreed to the use of their PBMCs and data for research purposes prior to blood sampling via written informed consent. All CRC patients and healthy donors agreed to anonymous publication of the resulting data. According to the Danish Regional Ethical Committee, assay validation does not have to be approved by the committee. Therefore, written informed consent was not required from the Danish anonymous healthy donor from which the buffy coat, included alone for validating flow cytometry, was obtained.

Open Access This article is distributed under the terms of the Creative Commons Attribution 4.0 International License (http://creativeco mmons.org/licenses/by/4.0/), which permits unrestricted use, distribution, and reproduction in any medium, provided you give appropriate credit to the original author(s) and the source, provide a link to the Creative Commons license, and indicate if changes were made.

\section{References}

1. Torre LA, Bray F, Siegel RL, Ferlay J, Lortet-Tieulent J, Jemal A (2015) Global cancer statistics,2012. CA Cancer J Clin 65(2):87-108

2. Schmoll HJ, Van Cutsem E, Stein A, Valentini V, Glimelius B, Haustermans K et al (2012) ESMO Consensus Guidelines for management of patients with colon and rectal cancer a personalized approach to clinical decision making. Ann Oncol 23(10):2479-2516. https://doi.org/10.1093/annonc/mds236

3. Van Cutsem E, Cervantes A, Nordlinger B, Arnold D; ESMO Guidelines Working Group (2014) Metastatic colorectal cancer: ESMO Clinical Practice Guidelines for diagnosis, treatment and follow-up. Ann Oncol Suppl 3:iii1-9

4. Rocca YS, Roberti MP, Arriaga JM, Amat M, Bruno L, Pampena $\mathrm{MB}$ et al (2013) Altered phenotype in peripheral blood and tumorassociated NK cells from colorectal cancer patients. Innate Immun 19(1):76-85. https://doi.org/10.1177/1753425912453187

5. Peng YP, Zhu Y, Zhang JJ, Xu ZK, Qian ZY, Dai CC et al (2013) Comprehensive analysis of the percentage of surface receptors and cytotoxic granules positive natural killer cells in patients with pancreatic cancer, gastric cancer, and colorectal cancer. J Transl Med 11:262. https://doi.org/10.1186/1479-5876-11-262

6. Ling KL, Pratap SE, Bates GJ, Singh B, Mortensen NJ, George BD et al (2007) Increased frequency of regulatory $T$ cells in peripheral blood and tumour infiltrating lymphocytes in colorectal cancer patients. Cancer Immun 7:7

7. Luckheeram RV, Zhou R, Verma AD, Xia B (2012) CD4(+) $T$ cells: differentiation and functions. Clin Dev Immunol 2012:925135. https://doi.org/10.1155/2012/925135

8. Zhang X, Kelaria S, Kerstetter J, Wang J (2015) The functional and prognostic implications of regulatory $\mathrm{T}$ cells in colorectal carcinoma. J Gastrointest Oncol 6(3):307-313. https://doi. org/10.3978/j.issn.2078-6891.2015.017

9. Aptsiauri N, Cabrera T, Mendez R, Garcia-Lora A, Ruiz-Cabello F, Garrido F (2007) Role of altered expression of HLA class I molecules in cancer progression. Adv Exp Med Biol 601:123-131

10. Menon AG, Morreau H, Tollenaar RA, Alphenaar E, Van Puijenbroek M, Putter H et al (2002) Down-regulation of HLA-A expression correlates with a better prognosis in colorectal cancer patients. Lab Invest 82(12):1725-1733

11. Watson NF, Ramage JM, Madjd Z, Spendlove I, Ellis IO, Scholefield $\mathrm{JH}$ et al (2006) Immunosurveillance is active in colorectal cancer as downregulation but not complete loss of MHC class I expression correlates with a poor prognosis. Int J Cancer 118(1):6-10. https://doi.org/10.1002/ijc.21303

12. Zeestraten EC, Reimers MS, Saadatmand S, Goossens-Beumer IJ, Dekker JW, Liefers GJ, van den Elsen PJ, van de Velde CJ, Kuppen PJ (2014) Combined analysis of HLA class I, HLA-E and HLA-G predicts prognosis in colon cancer patients. BrJCancer 110(2):459-468. https://doi.org/10.1038/bjc.2013.696

13. Sandel MH, Speetjens FM, Menon AG, Albertsson PA, Basse PH, Hokland $\mathrm{M}$ et al (2005) Natural killer cells infiltrating colorectal cancer and MHC class I expression. Mol Immunol 42(4):541-546. https://doi.org/10.1016/j.molimm.2004.07.039

14. Swets M, König MH, Zaalberg A, Dekker-Ensink NG, Gelderblom H, van de Velde CJ et al (2016) HLA-G and classical HLA class I expression in primary colorectal cancer and associated liver metastases. Hum Immunol 77(9):773-779. https://doi. org/10.1016/j.humimm.2016.03.001 
15. Chang CC, Campoli M, Ferrone S (2005) Classical and nonclassical HLA class I antigen and NK Cell-activating ligand changes in malignant cells: current challenges and future directions. Adv Cancer Res 93:189-234. https://doi.org/10.1016/S0065 -230X(05)93006-6

16. Caligiuri MA (2008) Human natural killer cells. Blood 112(3):461-469. https://doi.org/10.1182/blood-2007-09-077438

17. Vivier E, Tomasello E, Baratin M, Walzer T, Ugolini S (2008) Functions of natural killer cells. Nat Immunol 9(5):503-510. https ://doi.org/10.1038/ni1582

18. Cooper MA, Fehniger TA, Caligiuri MA (2001) The biology of human natural killer-cell subsets. Trends Immunol 22(11):633-640

19. Jonges LE, Albertsson P, van Vlierberghe RL, Ensink NG, Johansson BR, van de Velde CJ, Fleuren GJ, Nannmark U, Kuppen PJ (2001) The phenotypic heterogeneity of human natural killer cells: presence of at least 48 different subsets in the peripheral blood. Scand J Immunol 53(2):103-110

20. Biassoni R, Cantoni C, Pende D, Sivori S, Parolini S, Vitale M et al (2001) Human natural killer cell receptors and co-receptors. Immunol Rev 181:203-214

21. Dutertre CA, Bonnin-Gelize E, Pulford K, Bourel D, Fridman WH, Teillaud JL (2008) A novel subset of NK cells expressing high levels of inhibitory FcgammaRIIB modulating antibodydependent function. J Leukoc Biol 84(6):1511-1520. https://doi. org/10.1189/jlb.0608343

22. Addison EG, North J, Bakhsh I, Marden C, Haq S, Al-Sarraj S, Malayeri R, Wickremasinghe RG, Davies JK, Lowdell MW (2005) Ligation of CD8alpha on human natural killer cells prevents activation-induced apoptosis and enhances cytolytic activity. Immunology 116(3):354-361. https://doi.org/10.111 1/j.1365-2567.2005.02235.x

23. Bendelac A, Savage PB, Teyton L (2007) The biology of NKT cells. Annu Rev Immunol 25:297-336. https://doi.org/10.1146/ annurev.immunol.25.022106.141711

24. Makino Y, Kanno R, Ito T, Higashino K, Taniguchi M (1995) Predominant expression of invariant $\mathrm{V}$ alpha 14+ TCR alpha chain in NK1.1+ T cell populations. Int Immunol 7(7):1157-1161

25. Krijgsman D, Hokland M, Kuppen PJK (2018) The role of natural killer T cells in cancer-A phenotypical and functional approach. Front Immunol 9:367. https://doi.org/10.3389/fimmu.2018.00367

26. Campbell JJ, Qin S, Unutmaz D, Soler D, Murphy KE, Hodge MR, Wu L, Butcher EC (2001) Unique subpopulations of CD56+ NK and NK-T peripheral blood lymphocytes identified by chemokine receptor expression repertoire. J Immunol 166(11):6477-6482

27. van den Heuvel MJ, Peralta CG, Hatta K, Han VK, Clark DA (2007) Decline in number of elevated blood CD3(+) CD56(+) NKT cells in response to intravenous immunoglobulin treatment correlates with successful pregnancy. Am J Reprod Immunol 58(5):447-459. https://doi.org/10.1111/j.1600-0897.2007.00529.x

28. Chan WK, Rujkijyanont P, Neale G, Yang J, Bari R, Das Gupta N, Holladay M, Rooney B, Leung W (2013) Multiplex and genomewide analyses reveal distinctive properties of KIR+ and CD56+ T cells in human blood. J Immunol 191(4):1625-1636. https://doi. org/10.4049/jimmunol.1300111

29. Jiang Y, Cui X, Cui C, Zhang J, Zhou F, Zhang Z, Fu Y, Xu J, Chu Z, Liu J, Han X, Liao C, Wang Y, Cao Y, Shang H (2014) The function of CD3+CD56+ NKT-like cells in HIVinfected individuals. Biomed Res Int 2014:863625. https://doi. org/10.1155/2014/863625

30. Peng LS, Mao FY, Zhao YL, Wang TT, Chen N, Zhang JY, Cheng P, Li WH, Lv YP, Teng YS, Guo G, Luo P, Chen W, Zou QM, Zhuang Y (2016) Altered phenotypic and functional characteristics of CD3+CD56+ NKT-like cells in human gastric cancer. Oncotarget 7(34):55222-55230. https://doi.org/10.18632/oncot arget.10484
31. Li XF, Dai D, Song XY, Liu JJ, Zhu L, Zhu X, Ma W, Xu W (2017) A different representation of natural T cells and natural killer cells between tumor-infiltrating and periphery lymphocytes in human hepatocellular carcinoma. Oncol Lett 13(5):3291-3298. https://doi.org/10.3892/ol.2017.5808

32. Kim CH, Johnston B, Butcher EC (2002) Trafficking machinery of NKT cells: shared and differential chemokine receptor expression among V alpha $24(+) \mathrm{V}$ beta $11(+)$ NKT cell subsets with distinct cytokine-producing capacity. Blood 100(1):11-16. https://doi.org/10.1182/blood-2001-12-0196

33. Godfrey DI, MacDonald HR, Kronenberg M, Smyth MJ, Van Kaer L (2004) NKT cells: what's in a name? Nat Rev Immunol 4(3):231-237. https://doi.org/10.1038/nri1309

34. Maecker HT, Trotter J (2006) Flow cytometry controls, instrument setup, and the determination of positivity. Cytometry A 69(9): 1037-1042

35. Roederer M (2001) Spectral compensation for flow cytometry: visualization artifacts, limitations, and caveats. Cytometry 45(3):194-205. https://doi.org/10.1002/1097-0320(20011 101)45:3\%3c194:AID-CYTO1163\%3e3.0.CO;2-C

36. Benjamini Y, Hochberg Y (1995) Controlling the false discovery rate: a practical and powerful approach to multiple testing. J R Stat Soc Ser B 57(1):289-300

37. Galon J, Mlecnik B, Bindea G, Angell HK, Berger A, Lagorce C, Lugli A, Zlobec I, Hartmann A, Bifulco C, Pagès F (2014) Towards the introduction of the 'Immunoscore' in the classification of malignant tumours. J Pathol 232(2):199-209

38. Pagès F, Kirilovsky A, Mlecnik B, Asslaber M, Tosolini M, Bindea G, Lagorce C, Wind P, Marliot F, Bruneval P, Zatloukal K, Trajanoski Z, Berger A, Fridman WH, Galon J (2009) In situ cytotoxic and memory $\mathrm{T}$ cells predict outcome in patients with early-stage colorectal cancer. J Clin Oncol 27(35):5944-5951

39. Galon J, Costes A, Sanchez-Cabo F, Kirilovsky A, Mlecnik B, Lagorce-Pages C, Tosolini M, Camus M, Berger A, Wind P, Zinzindohoue F, Bruneval P, Cugnenc PH, Trajanoski Z, Fridman WH, Pages F (2006) Type, density, and location of immune cells within human colorectal tumors predict clinical outcome. Science 313(5795):1960-1964. https://doi.org/10.1126/scien ce. 1129139

40. Mlecnik B, Tosolini M, Kirilovsky A, Berger A, Bindea G, Meatchi T, Bruneval P, Trajanoski Z, Fridman WH, Pages F, Galon J (2011) Histopathologic-based prognostic factors of colorectal cancers are associated with the state of the local immune reaction. J Clin Oncol 29(6):610-618. https://doi. org/10.1200/JCO.2010.30.5425

41. Mlecnik B, Marliot F, Bindea G, Ou FS, Bifulco C, Lugli A, Zlobec I, Rau TT, Berger MD, Nagtegaal ID, Vink-Borger E, Hartmann A, Geppert C, Kolwelter J, Merkel S, Grutzmann R, Van den Eynde M, Jouret-Mourin A, Kartheuser A, Leonard D, Remue C, Wang JY, Bavi P, Roehrl MHA, Ohashi PS, Nguyen LT, Han S, MacGregor HL, Hafezi-Bakhtiari S, Wouters BG, Masucci GV, Andersson EK, Zavadova E, Vocka M, Spacek J, Petruzelka L, Konopasek B, Dundr P, Skalova H, Nemejcova K, Botti G, Tatangelo F, Delrio P, Ciliberto G, Maio M, Laghi L, Grizzi F, Fredriksen T, Buttard B, Angelova M, Vasaturo A, Maby P, Church SE, Angell HK, Lafontaine L, Bruni D, El Sissy C, Haicheur N, Kirilovsky A, Berger A, Lagorce C, Meyers JP, Paustian C, Feng Z, Ballesteros-Merino C, Dijkstra J, van de Water C, van Lent-van Vliet S, Knijn N, Musina AM, Scripcariu DV, Popivanova B, Xu M, Fujita T, Hazama S, Suzuki N, Nagano H, Okuno K, Torigoe T, Sato N, Furuhata T, Takemasa I, Itoh K, Patel PS, Vora HH, Shah B, Patel JB, Rajvik KN, Pandya SJ, Shukla SN, Wang Y, Zhang G, Kawakami Y, Marincola FM, Ascierto PA, Sargent DJ, Fox BA, Galon J (2018) International validation of the consensus Immunoscore for the classification of colon cancer: a prognostic and accuracy 
study. Lancet 391(10135):2128-2139. https://doi.org/10.1016/ S0140-6736(18)30789-X

42. Liu Z, Huang Q, Liu G, Dang L, Chu D, Tao K et al (2014) Presence of FOXP3(+)Treg cells is correlated with colorectal cancer progression. Int J Clin Exp Med 7(7):1781-1785

43. Wolf AM, Wolf D, Steurer M, Gastl G, Gunsilius E, Grubeck-Loebenstein B (2003) Increase of regulatory T cells in the peripheral blood of cancer patients. Clin Cancer Res 9(2):606-612

44. Campbell DJ, Koch MA (2011) Phenotypical and functional specialization of FOXP3+ regulatory T cells. Nat Rev Immunol 11(2):119-130

45. Lin YC, Mahalingam J, Chiang JM, Su PJ, Chu YY, Lai HY, Fang JH, Huang CT, Chiu CT, Lin CY (2013) Activated but not resting regulatory $\mathrm{T}$ cells accumulated in tumor microenvironment and correlated with tumor progression in patients with colorectal cancer. Int J Cancer 132(6):1341-1350. https://doi.org/10.1002/ ijc. 27784

46. Gharagozloo M, Rezaei A, Kalantari H, Bahador A, Hassannejad N, Maracy M, Nouri N, Sedghi M, Ghazanfari H, Bayat B (2018) Decline in peripheral blood NKG2D+CD3+CD56+ NKT cells in metastatic colorectal cancer patients. Bratisl Lek Listy 119(1):6-11. https://doi.org/10.4149/BLL_2018_002

47. Balsamo M, Manzini C, Pietra G, Raggi F, Blengio F, Mingari MC, Varesio L, Moretta L, Bosco MC, Vitale M (2013) Hypoxia downregulates the expression of activating receptors involved in NK-cell-mediated target cell killing without affecting ADCC. Eur J Immunol 43(10):2756-2764. https://doi.org/10.1002/eji.20134 3448

48. Vitale M, Cantoni C, Pietra G, Mingari MC, Moretta L (2014) Effect of tumor cells and tumor microenvironment on NKcell function. Eur J Immunol 44(6):1582-1592. https://doi. org/10.1002/eji.201344272

49. Han B, Mao FY, Zhao YL, Lv YP, Teng YS, Duan M, Chen W, Cheng P, Wang TT, Liang ZY, Zhang JY, Liu YG, Guo G, Zou QM, Zhuang Y, Peng LS (2018) Altered NKp30, NKp46, NKG2D, and DNAM-1 expression on circulating NK cells is associated with tumor progression in human gastric cancer. J Immunol Res 2018:6248590. https://doi.org/10.1155/2018/6248590

50. Valayer A, Brea D, Lajoie L, Avezard L, Combes-Soia L, Labas V, Korkmaz B, Thibault G, Baranek T, Si-Tahar M (2017) Neutrophils can disarm NK cell response through cleavage of NKp46. J Leukoc Biol 101(1):253-259. https://doi.org/10.1189/jlb.3AB03 16-140RR

51. Balsamo M, Scordamaglia F, Pietra G, Manzini C, Cantoni C, Boitano M, Queirolo P, Vermi W, Facchetti F, Moretta A, Moretta L, Mingari MC, Vitale M (2009) Melanoma-associated fibroblasts modulate NK cell phenotype and antitumor cytotoxicity. Proc Natl Acad Sci U S A 106(49):20847-20852. https://doi.org/10.1073/ pnas.0906481106

52. Li T, Yi S, Liu W, Jia C, Wang G, Hua X, Tai Y, Zhang Q, Chen $\mathrm{G}$ (2013) Colorectal carcinoma-derived fibroblasts modulate natural killer cell phenotype and antitumor cytotoxicity. Med Oncol 30(3):663. https://doi.org/10.1007/s12032-013-0663-z
53. Pietra G, Manzini C, Rivara S, Vitale M, Cantoni C, Petretto A, Balsamo M, Conte R, Benelli R, Minghelli S, Solari N, Gualco M, Queirolo P, Moretta L, Mingari MC (2012) Melanoma cells inhibit natural killer cell function by modulating the expression of activating receptors and cytolytic activity. Cancer Res 72(6):14071415. https://doi.org/10.1158/0008-5472.CAN-11-2544

54. Husain Z, Huang Y, Seth P, Sukhatme VP (2013) Tumor-derived lactate modifies antitumor immune response: effect on myeloidderived suppressor cells and NK cells. J Immunol 191(3):14861495. https://doi.org/10.4049/jimmunol.1202702

55. Rosental B, Brusilovsky M, Hadad U, Oz D, Appel MY, Afergan F, Yossef R, Rosenberg LA, Aharoni A, Cerwenka A, Campbell KS, Braiman A, Porgador A (2011) Proliferating cell nuclear antigen is a novel inhibitory ligand for the natural cytotoxicity receptor NKp44. J Immunol 187(11):5693-5702. https://doi. org/10.4049/jimmunol.1102267

56. Horton NC, Mathew SO, Mathew PA (2013) Novel interaction between proliferating cell nuclear antigen and HLA I on the surface of tumor cells inhibits NK cell function through NKp44. PLoS One 8(3):e59552. https://doi.org/10.1371/journ al.pone.0059552

57. Scurr M, Gallimore A, Godkin A (2012) T cell subsets and colorectal cancer: discerning the good from the bad. Cell Immunol 279(1):21-24. https://doi.org/10.1016/j.cellimm.2012.08.004

58. Choi J, Maeng HG, Lee SJ, Kim YJ, Kim DW, Lee HN, Namgung JH, Oh HM, Kim TJ, Jeong JE, Park SJ, Choi YM, Kang YW, Yoon SG, Lee JK (2018) Diagnostic value of peripheral blood immune profiling in colorectal cancer. Ann Surg Treat Res 94(6):312-321. https://doi.org/10.4174/astr.2018.94.6.312

59. Betts G, Jones E, Junaid S, El-Shanawany T, Scurr M, Mizen P, Kumar M, Jones S, Rees B, Williams G, Gallimore A, Godkin A (2012) Suppression of tumour-specific CD4(+) T cells by regulatory $\mathrm{T}$ cells is associated with progression of human colorectal cancer. Gut 61(8):1163-1171. https://doi.org/10.1136/gutjn 1-2011-300970

60. Roselli M, Formica V, Cereda V, Jochems C, Richards J, Grenga I, Orlandi A, Ferroni P, Guadagni F, Schlom J (2016) The association of clinical outcome and peripheral T-cell subsets in metastatic colorectal cancer patients receiving first-line FOLFIRI plus bevacizumab therapy. Oncoimmunology 5(7):e1188243. https://doi. org/10.1080/2162402X.2016.1188243

61. Xu T, Lu J, An H (2017) The relative change in regulatory T cells / T helper lymphocytes ratio as parameter for prediction of therapy efficacy in metastatic colorectal cancer patients. Oncotarget 8(65):109079-109093. https://doi.org/10.18632/oncotarget.22606

Publisher's Note Springer Nature remains neutral with regard to jurisdictional claims in published maps and institutional affiliations. 